\title{
СИНТЕЗ СОЕДИНЕНИЙ С ВЫСОКОЙ БИОЛОГИЧЕСКОЙ АКТИВНОСТЬЮ ПУТЕМ ПЕРЕХВАТА НИТРОКСИДОВ, ГЕНЕРИРУЕМЫХ ИЗ НИТРОСОЕДИНЕНИЙ В СРЕДЕ ФОСФОРНЫХ КИСЛОТ
}

\author{
Н.А. Аксенов ', Д.А. Аксенов', И.В. Аксенова', А.А. Скоморохов', \\ Д.С. Аксенова ${ }^{1}$ \\ ${ }^{1}$ Химико-фармацевтический факультет, Северо-Кавказский федеральный университет, \\ 355017, Россия, г. Ставрополь, ул. Пушкина, д. 1.
}

DOI: 10.19163/MedChemRussia2021-2021-25

E-mail:naksenov@ncfu.ru

В течение последних 10 лет одной из ключевых тем наших исследований выступали превращения алифатических нитросоединений в качестве $\alpha$-С-электрофильных реагентов в присутствии фосфорных кислот. Хотя представленная методология показала применимость к широкому кругу нуклеофилов различного строения и природы - от алифатических аминов до аренов, нерешенной оставалась задача определения действующего начала в этих превращениях.

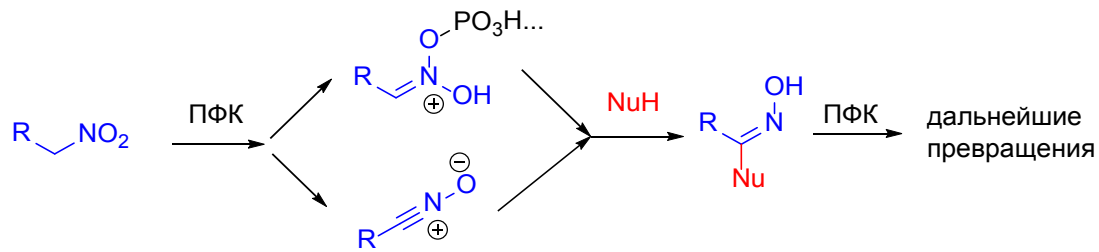

С этой целью нами был осуществлен перехват промежуточно образующихся нитрилоксидов в форме их [3+2] циклоаддуктов - фуроксанов и изоксазолов. Весьма интересным представляется высокая биологическая активность циклоаддуктов, содержащих арилоил- и алкилокси- группы, в то время как именно предшествующие им нитроуксусный эфир и 2-нитроацетофеноны показали наибольшую реакционную способность.

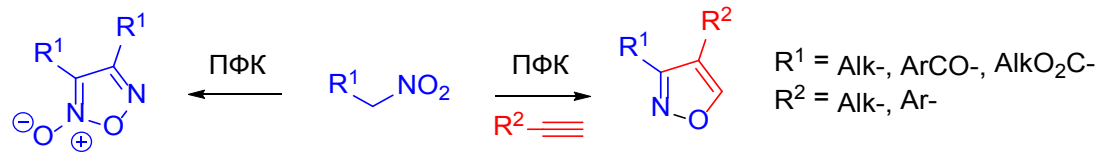

Работа выполнена при финансовой поддержке гранта Президента Российской Федерации для государственной поддержки молодых российских ученых докторов наук (грант № МД-3505.2021.1.3), а также Министерства образования и науки Российской Федерации (тема 0795-2020- 0031). 